Mirosława Ściupider-Młodkow ska

ORCID: 0000-0002-8700-2249

Uniwersytet im. Adama Mickiewicza w Poznaniu

\section{Rodzina i miłość w epoce Ja} Family and Love in the Time of Me

\begin{abstract}
ABSTRAKT
W artykule opisano rodzinę i miłość z perspektywy przemian obecnych w kulturze narcyzmu, takich jak relacje on-line, technicyzacja życia, komercjalizacja uczuć i terapeutyzacji życia. Inspiracja były teorie ukute przez światowej sławy badaczy, m.in. J-C. Kauffmana, N. Luhmana, Ch. Lascha, E. Beck-Gernsheim, U. Becka, A. Giddensa, E. Illouz, Z. Baumana i wielu innych, jak też badania własne autorki. Badania dotyczqce zwiqzzów partnerskich w biografiach młodzieży studiujqcej przeprowadzono w latach 2012-2016. Opublikowano je w ksiqzżce M. Ściupider-Młodkowskiej Miłość w epoce Ja. Studium socjopedagogiczne (Poznań 2018).

Główny obiekt narracji teoretycznej i wniosków metodologicznych $w$ niniejszych badaniach stanowiq relacje partnerskie opisane w skryptach młodzieży studiujqcej w wybranych uczelniach Polski i Czech.

Projekt badawczy monografii, mający charakter jakościowo-ilościowy, odpowiadał na pytanie: Jakie kulturowe wzory relacji partnerskich preferuje i praktykuje młodzież studiująca w Polsce i w Czechach oraz co je różnicuje? Tak postawiony przedmiot badań wymagał skonstruowania kilku narzędzi badawczych: rozbudowanej ankiety polskiej i czeskiej dla czterystu respondentów, wywiadu rozumiejqcego (J-C. Kauffmana) dla dwudziestu par heteroseksualnych oraz realnych $i$ wirtualnych debat $w$ ramach autorskiego fakultetu "Intymność pomiędzy byciem razem a osobno".
\end{abstract}

StOWA KLUCZOWE

miłość w epoce Ja, relacje $w$ pedagogice społecznej, kultura narcyzmu, uznanie i podglądactwo w mediach

KEYWORDS

love in the time of Me, relations in social pedagogy, the culture of narcissism, recognition and voyeurism in media

SPI Vol. 22, 2019/2

ISSN 2450-5358

e-ISSN 2450-5366 DOI: 10.12775/SPI.2019.2.005

Nadestano: 11.11.2018 Zaakceptowano: 10.06.2019

Artykuły i rozprawy 
Uzyskany dynamiczny obraz relacji partnerskich w biografiach młodzieży studiującej pozwolił na wyłonienie czterech kategorii skryptów biografii zwiq̨zkowej wśród studentów polskich i czeskich. Najwięcej polskich studentów (w tym przewaga kobiet) reprezentowało wzór skryptu biograficznego partnerstwa inicjowanego-tradycyjnego, ale silnie zindywidualizowanego, $z$ kolei studenci czescy reprezentowali w większości skrypty partnerstwa ponowoczesnego. Wyniki nie roszczq sobie praw do formułowania jednoznacznych tez, ale stanowiq propozycję konstruktywistycznej diagnozy na temat przemian obecnych w epoce Ja, której bohaterowie uwikłani w kulturowy narcyzm niejednokrotnie nie sq zdolni do trwałych relacji miłosnych, poszukując uznania i adoracji siebie w myśl zasady: Selfie ergo sum.

\section{ABSTRACT}

The theoretical part of this article draws on terminology defined by theorists such as J.C. Kauffman, N. Luhmannn, Ch. Lasch, E. Beck-Gernsheim and U. Beck, A. Giddens, L. Jamienson, E. Illouz, Z. Bauman. The research on partnership relations involved in a culture of narcissism have been published in the book by the author of the article: Ściupider-Młodkowska M., Love in the time of Me. A sociopedagogical study, Poznań 2018. The article describes the family and love from the perspective of transformations present in a culture of narcissism. The theoretical part of this article draws on terminology defined by theorists such as J.C. Kauffman, N. Luhmannn, Ch. Lasch, E. Beck-Gernsheim and U. Beck, A. Giddens, L. Jamienson, E. Illouz, Z. Bauman and the author's own research.

The research on partnership relations involved in narcissism culture have been published in a book by the author of the article: Ściupider-Młodkowska M., Love in the time of Me. A sociopedagogical study. Its theoretical narrative and methodological conclusions focus principally on partnership relations described in scripts from young people studying at selected universities in Poland and Czechia.

The research that led to this article was a qualitative-quantitative study aiming to answer the following question: Which cultural models of partner relations are preferred and practised by young people studying in Poland and Czechia and how do they differ? Such a subject required the construction of several research tools: extended questionnaires for 400 respondents in Polish and Czechia, an understanding interview 
(J-C. Kauffman) for two hundred heterosexual couples, and live and virtual debates as part of the author's course 'Intimacy between being together and separate'.

The dynamic picture of partner relations in the lives of Polish and Czech students allowed four categories of relationship history to be distinguished. Most Polish students (of whom more were female) represented the initiating-traditional partnership script, but a highly individualistic form, while the majority of Czech students fell into the category of postmodern partnership scripts. These results do not allow unambiguous theses but propose a constructivist diagnosis of current changes in the Me epoch, whose representatives are entangled in cultural narcissism, and are often unable to form lasting intimate relationships, instead seeking acknowledgement and self-adoration, in essence: Selfie ergo sum.

\section{Wstęp}

Rodzina stanowi podstawę do rozwijania i budowania społecznych, instytucjonalnych, kulturowych i niepowtarzalnych relacji potrzebnych wspólnocie. Rodzina i miłość silnie ze sobą kooperują. To rodzina daje podstawę do przeżywania miłości macierzyńskiej, ojcowskiej, siostrzanej, braterskiej, a także miłości toksycznej, której konsekwencje ponosi nie tylko osoba, która jej doświadczyła, ale całe następne pokolenia. Miłość raniąca, krzywdząca bardzo często nieświadomie niesie ze sobą piętno osamotnienia, wykluczenia i trudności w nawiązywaniu bliskich relacji związkowych. Dlatego też cały nurt psychologii humanistycznej, psychologii osobowości dostrzega ogromny wpływ doświadczeń związanych z tzw. miłością trudną, czy toksyczną, będących bezpośrednim źródłem problemów w życiu dorosłym, jak: depresja, alkoholizm, zakupoholizm, bulimia, anoreksja i wielu innych chorób z kręgu wymagających wsparcia i specjalistycznej pomocy. Wpływ i udział rozwijających się badań psychologicznych, będących pomocnymi w budowaniu wspólnoty i relacji, jest ogromny, niezwykle potrzebny i wartościowy.

Celem niniejszego artykułu jest zaakcentowanie, że współczesne zmieniające się uwarunkowania społeczno-kulturowe są paralelne $\mathrm{w}$ stosunku do uwarunkowań indywidualnych i rodzinnych, gdyż wpływają z równą siłą na rozumienie i definiowanie uczuć, 
emocjonalności, miłości, będących w centrum jakichkolwiek relacji. Miłość ma ogromną moc sprawczą, według Niklasa Luhmana ${ }^{1}$ obok pieniądza i władzy stanowi podstawę oddziaływania na całe struktury społeczne, tym bardziej warta jest analiz naukowych. Artykuł ukaże i zdefiniuje niektóre ogólnodostępne kody emocjonalności i miłości, które usankcjonowały konkretne badania, między innymi autorski projekt na temat biografii związkowych wśród młodzieży studiującej w wybranych uczelniach polskich i czeskich w latach 2013-2016².

Podjęty cel zanalizowania kształtu współczesnych relacji międzyludzkich jest uzasadniony z kilku względów.

Po pierwsze, $z$ jednej strony obserwujemy hybrydowość, różnorodność relacji rodzinnych zmienionych z modelu patriarchalnego na rzecz relacji dbających o jakość, ale też zaklasyfikowanych do relacji kruchych, efemerycznych, krótkotrwałych, często elektronicznych i wyimaginowanych. Biorąc pod uwagę, jak długą drogę przeszła tak zwana rodzina tradycyjna i jak znacząco zmienił się jej model z czasów preindustrialnych, nie można zostać obojętnym wobec przemian i zbadania ich zarówno w kontekście szans, jak i zagrożeń.

Po drugie, pedagogika społeczna, będąca in statu nascendi w wypracowaniu odpowiednich narzędzi i metod badających relacje on-line, w tym także w budowaniu odpowiedniej sieci wsparcia wobec obecnych w przestrzeni wirtualnej przestępstw: cyberstalkingu, sekstingu, sponsoringu, rozpoznaje tło społeczno-kulturowe i rodzinne odpowiedzialne za problemy społeczne. Zatem troska o jakość relacji rodzinnych i miłosnych, aby stanowiły bastion, nierozerwalną wspólnotę i sprowokowanie działań społecznych, politycznych, wspierających różne formy rodziny, jest uzasadniona.

1 N. Luhmann, Semantyka mitości. O kodowaniu intymności, przeł. J. Eoziński, Warszawa 2003.

2 Badania do dysertacji doktorskiej obronionej pod kierownictwem J. Modrzewskiego na Wydziale Studiów Edukacyjnych, realizowane dzięki stypendium Fundacji Uniwersytetu im. A. Mickiewicza w Poznaniu, w całości opublikowane w książce: Ściupider-Młodkowska M., Mitość w epoce Ja. Studium socjopedagogiczne, Poznań 2018. 


\section{Miłość w epoce Ja, czyli związi typu „exodus"}

Miłość obecna w kulturze narcyzmu, którą Christopher Lasch ${ }^{3}$ zauważył dwadzieścia siedem lat temu, gdy w społeczeństwie amerykańskim przemiany ekonomiczne i wzrost konsumpcji życia „zaowocowały" ogólnodostępnym trendem samodoskonalenia jednostki, ma swoje źródło w dążeniu do wymiernej korzyści i rywalizacji (walki o uznanie) w niemal każdej sferze życia. Miłość od tego momentu nie jest już jedynie indywidualnym projektem lecz została uwikłana w media, instytucje, rynek, reklamę, w dużej mierze kształtowana przez społeczne relacje płci i ekonomię. Taka relacja doczekała się często metaforycznych określeń w naukach społecznych, jak: bycie razem osobno (Zygmunt Bauman), miłość współbieżna albo czysta (Anthony Giddens), relacja zwana „bliskością w tle” lub intimate ambient (Shery Turkle). Wszystkie sformułowania i hasła wokół miłości, które jedynie zasygnalizowano, łączy znamienne poczucie niepewności i braku bezpieczeństwa, kładą bowiem silny akcent na emocje związane nie z bliskością ale samotnością/osamotnieniem, nie z jednością ale wykluczeniem, nie z poczuciem dumy ale wstydu, nie z odpowiedzialnością za podjęte decyzje ale krótkoterminowością i łatwością rozstania. Duch samodoskonalenia obecny w każdej sferze życia: zdrowotnej, intelektualnej, rodzinnej, zawodowej oraz kult kultury Ja poddający treningowi osobowość dążącą do wolnych decyzji, $\mathrm{w}$ dużej mierze manipulował związkami i relacjami międzyludzkimi oraz skłaniał do „zabójczej gry onieśmielania przyjaciół i uwodzenia ludzi”4, co z kolei rodziło cierpienie i osamotnienie.

Nie jest wielkim odkryciem, że zaangażowanie w relację miłosną od zawsze wiązało się z pewnym cierpieniem, tak pięknie opisanym chociażby w literackiej formie miłości romantycznej, czy sentymentalnej, w roli Romea i Julii czy Christiana i Izoldy. Współczesne relacje ranią nie tylko z przyczyn indywidualnego zaangażowania czy sprzeczności interesów i protekcji rodów pochodzenia kochanków, ale także (a może przede wszystkim) z przyczyn kulturowego narcyzmu, jak niepewność, chaos tożsamości, paniczne poszukiwanie uznania nie tylko w przestrzeni wirtualnej. Nauka, technologia i wpływy

3 Ch. Lasch, Kultura narcyzmu, Warszawa 2015.

4 Tamże, s. 93. 
polityczne w silnym stopniu zracjonalizowały miłość, jak udowadnia izraelska badaczka E. Illouz ${ }^{5}$. Zgodnie $\mathrm{z}$ analizami autorki, rozbuchane ogólnodostępne technologie pozwalające na bycie ogólnodostępnym poszukującym idealnego partnera zafałszowały intencje emocji; partnerzy, jako kreatorzy czy budowniczy - homo construens pogubili się, co stanowi cel relacji, czym jest zaangażowanie, poznanie drugiej osoby. Tym sposobem miłość uległa swego rodzaju odczarowaniu, skomercjalizowaniu, wymianie interesów.

Trafnie zjawisko wykreowanej internetowej relacji bez zaangażowania opisał Michał Wanke:

Być związanym $\mathrm{z}$ kimś $\mathrm{z}$ „bliskością $\mathrm{w}$ tle” to być obecnym w jego życiu ze swoją upublicznioną prywatnością. Być z kimś „razem osobno” (...) to odgrywać swoją tożsamość online- potencjalnie przed całym światem tych, którzy mają urządzenie z dostępem do sieci. Wreszcie być z kimś intimate ambient to podglądać strumień jego tożsamości bez zaangażowania, jakiego wymagałby tak nasycony informacjami związek poza światem Internetu 6 .

Bycie $\mathrm{w}$ ciągłym kontakcie $\mathrm{z}$ kimś daje iluzję bycia ważnym i potrzebnym, uwalnia od zobowiązań względem bliskich relacji rodzinnych, z drugiej strony łudzi obietnicą, że tego typu wirtualne zaangażowanie zapełni potrzebę niepowtarzalności, przezwycięży zwyczajność i niewidzialność w wielkim tłumie znajomych, czy tak zwanych "przyjaciół”, komentujących na forum zawiązywanie/zrywanie relacji.

Kultura narcyzmu, przejawiająca się $\mathrm{w}$ wyszukanych środkach komunikacji wirtualnej skierowanej na "Ja" jednostki, silnie wkracza w uczuciowość, tym samym przyczynia się do zmian w podejściu do ogólnych relacji międzyludzkich. Użytkownicy spotkań on-line nie Ozaprzestają stosowania pewnych antropotechnik w życiu codziennym. Korespondując, a nawet rozmawiając, operują pewnymi skrótami i kodami myślowymi, używając tak zwanych witaczy, emotikonów, lajków i innych symboli w nazewnictwie. Ponadto wielość wyboru partnera, oferowana na portalach randkowych i społecznościowych,

5 E. Ilouz, Dlaczego mitość rani. Studium socjologiczne, przeł. M. Filipczuk, Warszawa 2016.

6 M. Wanke, E-mocje, przypadki rozszerzonej rzeczywistości afektywne, w: Studia z socjologii emocji. Podręcznik akademicki, red. A. Czerner, E. Nieroba, Opole 2011, s. 291. 
przyzwyczaja jednostki żyjące jednocześnie w krajobrazie medialnych wrażeń do ciągłego głodu poszukiwania „lepszej opcji” i ciągłej potrzeby uznania w świecie realnym. Maria Czerepaniak-Walczak udowadnia, że mącenie w wartościach, wszelkiego rodzaju zaburzenia i braki osobowościowe występują z taką samą siłą i częstotliwością zarówno w środowiskach cierpiących na niedobory emocjonalne, socjalne, co w socjalizacji pełnej nadmiaru i obfitości.

Doświadczenia życia codziennego w warunkach obfitości, przeładowania, stłoczenia, przeciążenia, bogactwa, naddatków i innych przejawów nadmiaru także mogą przeciążać i wyczerpywać zasoby fizyczne, emocjonalne i intelektualne oraz prowadzić do zaburzeń.

Wraz z użyciem coraz bardziej wyrafinowanych technicznie środków poszerza się zakres treści i form upowszechniania wzorów i norm relacji społecznych oraz pracy nad sobą. Zwiększa się przy tym zamęt w obszarze wzorców osobowego i społecznego rozwoju?

Zamęt ten ma wpływ na deprecjacje i dewaluacje pojęcia „My” na rzecz nobilitacji „Ja” w biografiach związkowych.

W latach osiemdziesiątych w tygodniku „Polityka” opublikowano artykuł charakteryzujący polski model kobiet z lat 1980-1989, w którym kobiety „marzą o bogatym mężu i domku z ogródkiem, ale zburzą te marzenia, gdy tylko przekonają się, jak ograniczający bywa taki model życia” ${ }^{8}$. W tych latach rośnie popularność „książek z serduszkiem”, czyli harlequinów, które opisują piękne młode kobiety, romansujące, dążące do podmiotowego traktowania w związkach, uciekające od monotonii małżeństw i negocjujące swoją pozycję w relacji miłosnej. Dziś swego rodzaju odskocznię od realnych kontaktów pełnią portale randkowe i opiniotwórcze rzesze terapeutów, ekspertów i elit odpowiedzialnych za tzw. refleksyjny model związków uczuciowych. Trzydzieści, czterdzieści lat temu kobiety uciekające w świat książkowych romansów raczej nie podejmowały odważnych, ryzykownych decyzji o rozstaniu, separacji czy rozwodzie ze

7 M. Czerepaniak-Walczak, Socjalizacja akademicka w czasach nadmiaru. O socjalizacji w (akademickim) krajobrazie medialnym, w: Pedagogika w spoteczeństwie - społeczeństwo w pedagogice, red. A. Matysiak-Błaszczyk, E. Włodarczyk, Poznań 2016, s. 195-200.

8 Portrety kobiet i mężczyzn w środkach masowego przekazu oraz podręcznikach szkolnych, red. R. Siemieńska, Warszawa 1997, s. 38. 
swoim obecnym partnerem. Czytanie tego typu literatury lekkiej służyło raczej rozrywce, dziś świat spotkań z wirtualnym kochankiem, $\mathrm{z}$ rozrywki przekształcił się $\mathrm{w}$ angażujące emocjonalnie i czasowo kontakty.

W kulturze zwierzeń internetowych jednostki tworzące związki realne naturalnie, spontanicznie i chętnie korzystają także z przestrzeni medialnej, która bardzo często wprowadza dezorganizację i zaburza dotychczasowe życie emocjonalne i intymne, skutkując rozpadem tradycyjnych relacji. Internet oraz świat techniki daje duże pole dostarczania i pobierania informacji o sobie i o innych, tym samym użytkownicy są skazani na „przymusowy” bądź nieuświadomiony „voyeuryzm” $\mathrm{i}$ podglądactwo. Portale randkowe i społecznościowe, z których korzystają pary, są swoistymi bazami danych o partnerach. $Z$ reguły wystarczy jeden pozytywny bądź negatywny komentarz, a nawet słowo upublicznione, na przykład na portalu społecznościowym Facebook, a staje się to powodem awantury i rozpadu relacji realnej. W polskich sądach coraz częstszym powodem rozwodu są właśnie zdrady internetowe.

Rafał Ilnicki ${ }^{10} \mathrm{w}$ nurcie filozoficznej refleksji nad technicyzacją kultury wprost mówi o tym, że każdy użytkownik przestrzeni on-line posiada swój wirtualny habitus cyberkulturowy, czyli „traktuje otaczający go świat na wzór tych sposobów bycia, które podsuwa mu technologia”. Idąc tym tropem, Ja jednostki w coraz większym stopniu inwestuje $\mathrm{w}$ techniki uzewnętrzniania siebie, chcąc zaistnieć w cyberkulturze. Dewaluacja wspólnoty następuje na skutek ujawniania tylko zewnętrznego Ja, które nadyma się różnymi możliwościami retuszowania swojej tożsamości, chwalenia się głównie osiągnięciami - także w relacjach miłosnych. Prawdziwe Ja przestaje istnieć, następuje jego dezintegracja, podobnie jak przestaje istnieć realna wspólnotowość w związku, bo jednostka narcystyczna szybko uzależnia się od pochlebstw w świecie wirtualnym, a co gorsza chce czerpać $\mathrm{z}$ tego jedyną satysfakcję.

9 Pojęcie voyeuryzmu oznacza podglądanie medialnych sytuacji i zdarzeń, które uruchamiają u oglądającego fantazje, impulsy (także seksualne) i wprowadzają uczucie dyskomfortu i frustracji z powodu niemożności realizacji nierealnych i nieosiagalnych pragnień.

10 R. Ilnicki, Wirtualny habitus cyberkultury, „Hybris” 2015, nr 31, s. 137. 
Wirtualny świat spotkań stwarza iluzję jednostki wolnej, dążącej do spełnienia w każdej sferze życia. Poprzez silną racjonalizację wszystkich pragnień ludzkich wytworzył się nowy typ związków zwanych „exodus”, czyli uciekających od prawdziwych relacji. Związki te wytworzyły pewien schemat (habitus) bycia razem, w którym oddalają decyzje o stabilizacji i małżeństwie, a nawet realnym spotkaniu. Uciekają głównie od tradycyjnych wzorców związkowych, które krępują, oraz od mody, która się demokratyzuje. Związki typu „exodus” lokują swoje wybory w paradoksach, preferując na przykład bezdzietność z miłości do dzieci, czy też miłosne relacje internetowe $\mathrm{z}$ powodu osamotnienia, bycie singlem $\mathrm{w}$ życiu realnym, ale upublicznioną i podziwianą parą w świecie wirtualnym.

Związki typu „exodus” doświadczają asocjacyjnej funkcji Internetu w zamian za trwałe i stabilne relacje; wirtualne spotkania pozwalają tylko na ich substytut, oferując folklor wrażeń, dowartościowują jedynie zewnętrzny wizerunek jednostek i par. Pary zawiązywane i utrzymywane wyłącznie przez Internet, utrzymujące typ związku uciekającego od realnych spotkań, zaadaptowały i wdrożyły w życie te antropotechniki, które narzucił im system. Separują się i emancypują od otoczenia materialnego jako czegoś gorszego, mniej stymulującego aniżeli np. wirtualne spotkanie z fantastycznie prezentującym się i pod każdym względem atrakcyjnym partnerem. Należy podkreślić, że spotkania on-line bardzo silnie angażują emocjonalnie i czasowo. Nieustanne fantazjowanie o tym, że można stworzyć związek bez skazy, to żniwo zaszczepienia narcystycznej wizji, że relacja nie może być zwyczajna, bo poświęciliśmy zbyt wiele czasu i energii właśnie na to, aby zaimponować i upublicznić jej niezwykłość.

System wirtualnych spotkań wdraża w odpowiedni schemat wyglądu, prezentacja wizerunku jednostki ulega retuszowi. Pod pozorem jednostek atrakcyjnych, emancypacyjnych, odważnych, jednocześnie kryje się mocno zhomogenizowany świat myśli, wartości, a nawet wyglądu. Okazuje się, że w obietnicy podkreślania dystynktywnych różnic świat on-line czyni jednostki i pary nieodróżnialnymi z danego kręgu, grupy, portalu. W tym homogenicznym świecie nadmiaru, i obfitości, przeładowania, przeciążenia, bogactwa informacji o nas o innych, dochodzi do osłabienia i wyczerpania czujności emocjonalnej. Trudno się dziwić, że tak częstym powodem osobistych i rodzinnych tragedii: rozstań, rozwodów, krzywd i traumatycznych przeżyć 
są właśnie relacje wirtualne, wymagające coraz większej refleksji i profesjonalnego wsparcia społecznego.

Badania Marty Majorek z 2015 roku, dokumentujące kody You Tube pod względem kultury partycypacji i kultury kreatywności $\mathrm{z}$ wielkim niepokojem prezentują, że intymne i osobiste treści zaczynające się $\mathrm{z}$ reguły od niewinnej autoprezentacji siebie wśród nastolatek oraz młodzieży do trzydziestego roku życia, bardzo często szokują przekazem zawartych w nich treści erotycznych.

Wiele miejsca [w Internecie, a dokładnie na You Tube - M.Ś-M.] poświęca się problemowi przedstawiania kobiet jako przedmiotów mających służyć zaspokajaniu męskich potrzeb seksualnych. Nie trzeba wykazywać się szczególnymi umiejętnościami, żeby odnaleźć tysiące filmów, które zdawać by się mogło, odzwierciedlają ten osąd. Wystarczy kilka kliknięć, by oglądać amatorskie nagrania prezentujące występy kobiet, zawierające zwykły taniec, a także przedstawiające obrazy od tego dalekie. Mowa tutaj o manifestowaniu przez wykonawczynie swej seksualności, co realizowane jest przez wideo ze striptizem (...) czy jednak tego typu wideo są przejawem wyłącznie uprzedmiotowienia kobiet, czy należy się kierować nasyconymi mizoginicznymi treściami komentarzami oglądających, czy też należałoby zmienić nieco punkt widzenia i zapatrywanie na tego typu występy ${ }^{11}$.

Z powyższych ustaleń wynika, że seksualna bliskość, a raczej konwersja bliskości fizycznej na wirtualną, oddzielona od emocji jest jedynie ucieczką, prowadzi do dramatów osobowościowych, potęgując osamotnienie i depersonalizację relacji międzyludzkich. Podobnie jak mitologiczny Narcyz, przyglądający się bez końca swojemu odbiciu, panicznie bał się odrzucenia, nie był szczęśliwy.

\section{Narcyzm jednostkowy a narcyzm społeczny}

Liberalne społeczeństwa zorganizowane wokół konsumpcji i przyjemności narzucają jednostkom wszelkie formy zachowania narcystycznego, jak np. zafascynowanie sławą, celebrowanie swoich osiągnięć, krótkoterminowość i brak stabilnego miejsca zamieszkania, pracy, rozbudzają oczekiwania społeczne, nie gwarantując ich spełnienia. $Z$ jednej strony prowokują do poszukiwania szczęścia za

11 M. Majorek, Kod YouTube. Od kultury partycypacji do kultury kreatywności, Kraków 2015, s. 124-125. 
wszelką cenę, z drugiej odrzucają poczucie słabości, bezradności czy współczucia dla innych.

W psychologii osobowości ${ }^{12}$, diagnozując zespół osobowości narcystycznych wyraźnie podkreśla się dezintegrację słabego „Ja” jednostki, która żyje w permanentnym lęku i zagrożeniu przed atakami na samego siebie, jest zawistna, gardzi zaletami i dobrami innych, panicznie boi się odrzucenia, ale często je prowokuje swoją agresją. Zupełnie inaczej prezentuje się na zewnątrz, jest fałszywa i nadyma się różnymi wspaniałymi zasługami, zdaje się być silna i niezwyciężona. Narcyzm kulturowy skutecznie wmawia jednostkom swoją wyjątkowość, oryginalność i bezinteresowność, pod pozorem wolnego wyboru funduje społeczeństwu wybór silnie zinstrumentalizowany rynkowo.

Cechy dystynktywne narcyzmu jednostkowego to przekonanie o swojej wyjątkowości i wielkości oraz nieustanne dążenie do admiracji i wzbudzania zazdrości ze strony otoczenia. Jednostki narcystyczne karmią się wizjami o swoim sukcesie, władzy, bogactwie, kosztem emocjonalności i uczuciowości swojej i innych, dążą do ideału w każdej dziedzinie. Jednostka nastawiona jest wyłącznie na realizację własnego „Ja”, tym samym nie może zrozumieć potrzeb drugiego człowieka. Jakikolwiek wymóg stawiany przez otoczenie zostaje przez jednostkę narcystyczną odczytany jako zniewolenie i ograniczenie jej wolności i przestrzeni. Skrajny typ narcyzmu można porównać do solipsyzmu (z łac. solus ipse - ja sam), poglądu filozoficznego, w którym podmiot widzi jedynie siebie, zasługującego na bezwzględny podziw, adoracje, zachwyt i podmiotowe traktowanie, przy czym wszystkich wokól siebie uprzedmiotawia.

W epoce "Ja"13 obfitują indywidualne pomysły, które zupełnie ignorują kontekst społeczno-kulturowy, jednocześnie te same indywidualne projekty nie spajają tożsamości par, a jedynie wywyższają Ego jednostki. Widać to wyraźnie w terapeutycznych sposobach ratowania par, które paradoksalnie na rozbijający związki indywidualizm stosują praktyki mające wyłącznie podreperować i podbudować indywidualną wartość i Ego jednostki.

12 Psychologia zachowań osobowości. Wybrane zagadnienia, red. L. Cierpiałkowska, Poznań 2004.

13 Określenie użyte przez U. Becka i E. Beck-Gernheim w: Mitośc na odlegtość. Modele życia w epoce globalnej, przeł. M. Sutowski, Warszawa 2013. 
Z powyższego wynika, że narcyzm jako źródło zaburzeń jednostkowych człowieka koresponduje z narcyzmem kulturowym. Stało się tak między innymi na skutek atrofii socjalizacji bezpośredniej, pochodzącej od rodziny, szkoły, rówieśników. Współczesne społeczeństwo, w którym przychodzi młodym ludziom, zdanym wyłącznie na siebie, przygotowywać się do pełnienia ról społecznych, przyczynia się do narcystycznych postaw. Młodzież czerpie wiedzę z nigdy nie kończących się medialnych pomysłów na „najlepszy, najoryginalniejszy autowizerunek", które nakazują nieustannie podążać za tym, co aktualne i zmieniać dotychczasowe wartości na rzecz innych, skupionych głównie wokół posiadania. Ponadto rozprzestrzenianie narcystycznych postaw w kulturze uniemożliwia empatię na krzywdy społeczne, spowalnia reakcje na jakiekolwiek problemy innych, które nie są obejmowane refleksją; taka postawa skutecznie odpiera także autokrytycyzm. Na piedestale wyborów stoi jednostkowe zaspokajanie pragnień i „pozorna” wolność.

Kultura narcyzmu przyczynia się zatem do dystansu społecznego. Pod pozorem pracy nad sobą, autoanaliz i niezależności, „wolna” jednostka koncentruje się raczej na kolekcjonowaniu indywidualnych doznań, także w związku partnerskim. Jak kwituje Wojciech J. Burszta:

(...) współczesny narcyz tkwi po uszy w ideologii konsumpcyjnej, walczy nieustannie, aby on i jego rodzina miały więcej i lepiej, a konkurencja innych wymusza, aby nieustannie dbał o własny status, styl życia i tożsamość podmiotową, opartą na fetyszyzmie podmiotowym ${ }^{14}$.

Ponadto, jak słusznie zauważa ten autor, kultura narcyzmu powoduje zamęt tożsamościowy, myli pojęcie tożsamości i osobowości Ja $\mathrm{z}$ doświadczeniem Ego.

Ego jednostki jest zmienne, dopasowane do odbioru społecznego i panujących w danej kulturze, wzorców tworzenia relacji. Ego doświadcza często relacji krótkotrwałej, opartej na romansie, czy tak zwanych przyjaźniach z plusem (czyli przyjaźni z jednorazową, niezobowiązującą przygodą seksualną). Prawdziwą tożsamość, osobowość i związek buduje się w realnym i stałym kontakcie $\mathrm{z}$ innymi bliskimi, nie można ich zatem traktować jak zbiór doświadczeń

14 W.J. Burszta, Narcyzm, kontrkultura i styl życia. W strone kulturoznawstwa krytycznego, w: cyfroteka.pl/katalog/ebooki? [dostęp: 6.08.2015]. 
i projektów do zdobycia, a następnie porzucenia na rzecz „atrakcyjniejszych" pomysłów.

Zogniskowanie na samym sobie jako dominująca cecha promowana przez kulturę narcyzmu nakazuje spoglądać na budowanie związku właśnie w kategorii towaru, w który należy inwestować, a jeśli inwestycja się nie opłaca, nieustannie wymieniać, niczym w transakcji handlowej. Związki korzystają coraz częściej z porad internetowego love coacha, którego zadaniem ma być wirtualnie nauczyć umiejętności kochania i spełnić potrzebę bycia kochanym. Doradcy od miłości koncentrują się $\mathrm{w}$ pracy z klientem na zmianie podejścia do szukania partnera, na budowaniu wartości osoby. To love coach definiuje relacje „zdrowe”, czyli szczęśliwe i satysfakcjonujące dla indywidualnej jednostki. Problem polega na tym, że silna koncentracja na osobie, jej pragnieniach, przełamywaniu barier, lęków i ciągłe przyglądanie się jednostce bardziej uczy narcystycznych aniżeli partnerskich skryptów bycia razem. Współczesne pary są skutecznie przekonywane o słuszności i konieczności urozmaicania związku, o tym, że nie może on tracić na atrakcyjności, rozumianej w kategorii posiadania (przystojnego i bogatego partnera, seksownej partnerki, stuprocentowej matki, żony, udanego życia seksualnego, bycia spełnionym), i to wszystko jest do osiągnięcia pod warunkiem pracy $\mathrm{z}$ love coachem. Jean Twenge ${ }^{15}$ amerykańska badaczka „Pokolenia My” z przerażeniem stwierdza, że na przestrzeni dwudziestu lat poziom narcyzmu wśród młodych ludzi, nie potrafiących realnie ocenić samych siebie i swoich potrzeb oraz nieumiejętnie selekcjonujących potrzeby, wzrósł aż o sześćdziesiąt pięć procent. Winą za ten fakt obarcza właśnie skuteczne mechanizmy kultury narcystycznego chwalenia i nagradzania jednostek, które na pochwały i nagrody nie zasłużyły. Jednocześnie wybujała pewność siebie i koncentracja na swoim wizerunku udoskonalanym poprzez markę, modę, posiadanie dotyczy częściej jednostek serwilistycznych, które bezkrytycznie chłoną trendy narzucane przez media, a ich liczba w społeczeństwie rośnie (narcyzm kulturowy odbiera autokrytycyzm).

Zatem mechanizmem, który napędza narcyzm kulturowy, jest rynek i reklama oraz ich wszechogarniające możliwości mącenia

15 J.M. Twenge, W. Keith, The Narcissism Epidemic: Living in the Age of Entitlement, New York 2009. 
w wartościach, deprecjonowania wiedzy, inteligencji i mądrości, a wystawiania na piedestał kultu młodości, posiadania a przede wszystkim „zbawczej” roli podziwu i rozgłosu. Badacz życia społecznego Alain Touraine słusznie zauważa, że „Wynoszenie prywatnego życia do rangi sprawy publicznej jest dziś jednym z najbardziej nośnych czynników stratyfikujących, a więc nie dziw, że jest też jednym z najbardziej upragnionych przywilejów"16.

Wiele uwagi poświęca się współcześnie pytaniom o styl życia, niegdyś definiowany jako cechy charakteru pozwalające na określone reakcje i zachowania (za Alfredem Adlerem), dziś rozumiany raczej w kategoriach sukcesu, posiadania i upubliczniania „kim jestem”. Na portalach społecznościowych można poddać publicznej ocenie własny wizerunek, samopoczucie, własny, choć zmienny styl życia. Typowa jednostka o zaburzeniu narcystycznym, żyjąca w kulturze pełnej narcystycznych wizji, chce brylować w otoczeniu, każdą rolę odgrywając $\mathrm{w}$ sposób przedmiotowy, chce być widziana i podziwiana, bez względu na swoje i innych odczucia. Jednocześnie jest w swoich zachowaniach utwierdzana jako oryginalna, godna podziwu i naśladowania. Magdalena Szpunar ${ }^{17}$ oraz Beata Świątek ${ }^{18}$ pisząc o narcyzmie jednogłośnie przyznają, że narcyzm jednostkowy może zaburzać całe życie społeczne i przenosić się do całych kultur uwikłanych w ekstazę wrażeń, szokowania i podziwiania jednocześnie.

\section{Zakończenie}

Pedagogika społeczna, której misja sprowadza się do pomagania, nie zawęża swojej działalności badawczej i naukowej tylko do osób z kręgu: biednych, bezdomnych, bezrobotnych i osamotnionych. Aktualne pytania pedagogiki społecznej daleko wykraczają poza pomoc społeczną oraz system świadczeń, ukazując nowy teren wsparcia dla relacji rodzinnych w warunkach zmian kulturowych.

16 A. Touraine, Po kryzysie, przeł. M. Frybes, Warszawa 2013, s. 319.

17 M. Szpunar, Od narcyzmu jednostki do kultury narcyzmu, „Kultura - Media Teologia” 2014, nr 18, s. 106-116.

18 B. Świątek, Narcyzm jako źródto zaburzeń orientacji życiowych cztowieka, w: Narcyzm, red.J. Sieradzan, Białystok 2011, s. 187. 
Pedagodzy społeczni badający rodzinę coraz częściej akcentują zmiany jednostkowe i społeczno-kulturowe związane $\mathrm{z}$ technicyzacją życia, które wpływają na jakość i kształt miłości oraz doświadczanych problemów w relacjach związkowych i rodzinnych.

Cała sieć problemów społecznych, związanych z sekstingiem, sponsoringiem, prostytucją, cyberprzemocą i cyberpornografią, nie stanowi wyłącznie zadania dla profesjonalnego wsparcia psychologicznego. Odpowiedzialność za treść i transfer sfery aksjonormatywnej ponoszą wszystkie struktury instytucjonalno-kulturowe, w tym przede wszystkim trójjednia przestrzeni edukacyjnych: rodzina szkoła (także szkoła wyższa) - rówieśnicy.

\section{Bibliografia}

Beck U., Beck-Gernsheim E., Catkiem zwyczajny chaos mitości, Dolnośląska Szkoła Wyższa, Wrocław 2013.

Beck U., Beck-Gernsheim E., Mitość na odlegtość. Modele życia w epoce globalnej, przeł. M. Sutowski, Wydawnictwo Naukowe PWN, Warszawa 2013.

Burszta W., Narcyzm, kontrkultura i styl życia. W stronę kulturoznawstwa krytycznego, w: cyfroteka.p1/katalog/ebooki? [dostęp: 6.08.2015].

Burszta W., Majewski M., Sekuła E.A., Tożsamość i samotnośc: komentarze mtodego pokolenia, Wydawnictwo Szkoła Wyższa Psychologii Społecznej „Academica”, Warszawa 2011.

Bieńko M., Intymne i prywatne praktyki codzienności. Studium socjologiczne, Wydawnictwa Uniwersytetu Warszawskiego, Warszawa 2013.

Czerepaniak-Walczak M., Socjalizacja akademicka w czasach nadmiaru. O socjalizacji w (akademickim) krajobrazie medialnym, w: Pedagogika w spoteczeństwie - spoteczeństwo w pedagogice, red. A. Matysiak-Błaszczyk, E. Włodarczyk, Wydawnictwo Naukowe UAM, Poznań 2016, s. $195-200$.

Ilnicki R., Wirtualny habitus cyberkultury, „Hybris” 2015, nr 31, s. 134-154. Ilouz E., Dlaczego mitość rani. Studium socjologiczne, przeł. M. Filipczuk, Wydawnictwo Krytyki Politycznej, Warszawa 2016.

Lasch C., The Culture of Narcissism: American Life in An age of Diminishing Expectations, New York Times, New York 1991.

Luhmann N., Semantyka mitości. O kodowaniu intymności, przeł. J. Łoziński, Wydawnictwo Naukowe Scholar, Warszawa 2003.

Majorek M., Kod YouTube. Od kultury partycypacji do kultury kreatywności, Universitas, Kraków 2015.

Musiał M., Intymnośc i jej wspótczesne przemiany. Studium z filozofii kultury,

Wydawnictwo Naukowe UAM, Kraków 2015. 
Portrety kobiet i mężczyzn w środkach masowego przekazu oraz podręznikach szkolnych, red. R. Siemieńska, Uniwersytet Warszawski. Instytut Studiów Społecznych. Wydawnictwo Naukowe Scholar, Warszawa 1997.

Psychologia zachowań osobowości, Wybrane zagadnienia, red. L. Cierpiałkowska, Wydawnictwo Naukowe UAM, Poznań 2004.

Szlendak T., Socjologia rodziny. Ewolucja, historia, zróżnicowanie, Wydawnictwo PWN, Warszawa 2010.

Szpunar M., Od narcyzmu jednostki do kultury narcyzmu, „Kultura - Media Teologia" 2014, nr 18, s. 106-116.

Ściupider-Młodkowska M., Mitość w epoce Ja. Studium socjopedagogiczne, Wydawnictwo Naukowe UAM, Poznan 2018.

Świątek B., Narcyzm jako źródto zaburzeń orientacji życiowych cztowieka, w: Narcyzm, red.J. Sieradzan, Wydawnictwo Uniwersytetu w Białymstoku, Białystok 2011, s. 186-196.

Touraine A., Po kryzysie, przeł. M. Frybes, Wydawnictwo Oficyna Naukowa, Warszawa 2013.

Twenge J.M., Keith W., The Narcissism Epidemic: Living in the Age of Entitlement, Free Press, New York 2009.

Wanke M., E-mocje, przypadki rozszerzonej rzeczywistości afektywne, w: Studia z socjologii emocji. Podręcznik akademicki, red. A. Czerner, E. Nieroba, Wydawnictwo Uniwersytetu Opolskiego, Opole 2011, s. 279-300.

\section{ADRES DO KORESPONDENCJI}

Dr Mirosława Ściupider-Młodkowska

Uniwersytet im. Adama Mickiewicza w Poznaniu

Wydział Pedagogiczno-Artystyczny

Zakład Nauk o Edukacji

e-mail:miriamus@amu.edu.pl 